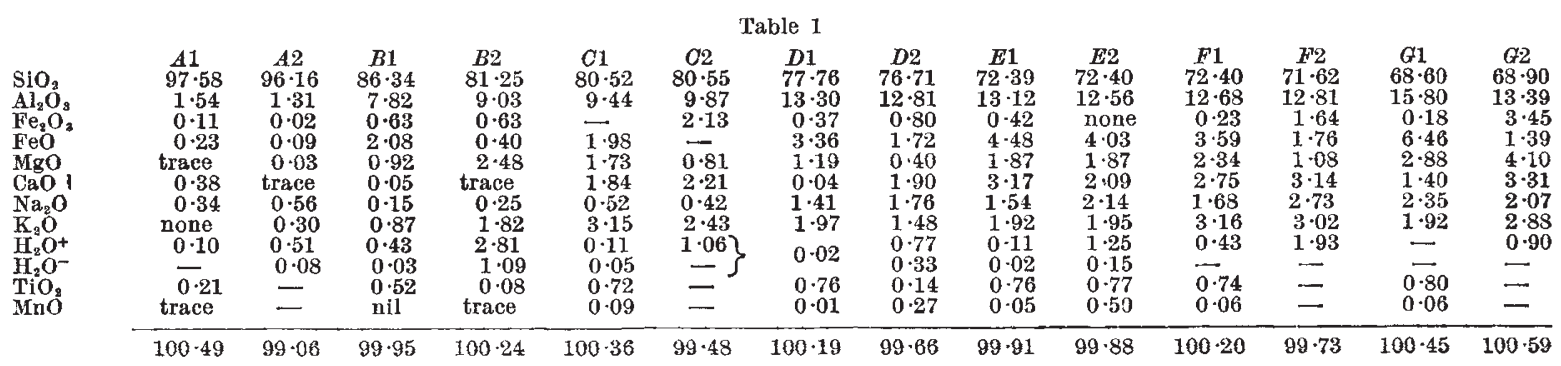

A1, Libyan Desert glass (Univ. Texas Pub. 3945, anal. 65).

A2, Granite (marginal variety). Eskdale, England (U.S. Geol. Surv. Prof. Paper 99, 51).

$B 1$, Darwin glass (also $\mathrm{ZrO}_{2}, 0 \cdot 11$ ) (Univ. Texas Pub. 3945, anal. 1)

B2, Metarhyolite, Shasta Co., Calif. (also S, $0 \cdot 35$; BaO, 0.05) (U.S. Geol. Surv. Prof. Paper 99, 51).

C1, Moldavite (Univ. Texas Pub. 3945, anal. 12).

C2, Felsite, Co. Waterford, Ireland (U.S. Geol. Surv. Prof. Paper 99, 53).

D1, Bediasite (Univ. Texas Pub. 3945, anal. 16).

D2, Granite, Settsu, Japan (also $\mathrm{P}_{8} \mathrm{O}_{5}, 0.48 ; \mathrm{ZrO}_{2}, 0.03 ; \mathrm{S}, 0.06$ ) (U.S. Geol. Surv. Prof. Paper 99, 53).

$E_{1}$, Australite (also NiO, 0.06) (Univ. Texas Pub. 3945, anal. 56).

E2, Granite, Reefton, New Zealand (aIso $\mathrm{P}_{8} \mathrm{O}_{5}, 0.09 ; \mathrm{SO}_{8}, 0.08$ ) (U.S. Geol. Surv. Prof. Paper 99, 331).

F1, Indochinite (also $\mathrm{P}_{2} \mathrm{O}_{5}, 0 \cdot 14$ ) (Univ. Texas Pub. 3945, anal. 40)

F2, Granite, Styria, Austria (U.S. Geol. Surv. Prof. Paper 99

G2, Quartz diorite, Corsica (also $\mathrm{P}_{2} \mathrm{O}_{5}, 0 \cdot 20$ ) (U.S. Geol. Surv. Prof. Paper 99, 331).

must have originated by the fusion of sedimentary rocks is unwarranted.

American Museum of Natural History,

Brtan Mason

New York 24.

Dec. 12.

1 Urey, H. C., Nature, 182, 1078 (1958).

${ }^{2}$ Barnes, v. E., Oniv. Texas Pub., 3945 (1940).

${ }^{3}$ Washington, H. S., U.S. Geol. Surv. Prof. Paper 99 (1017).

\section{Glaciation in the Jammu Hills}

Much evidence of the last or Pleistocene Ice Age has been observed in various parts of the Central and the Lesser Himalayas. Lieut.-Col. J. L. Grinlinton has referred to the shape of polished and striated or grooved rock surfaces in the Liddar and Sind Valleys of the Kashmir Himalayas'. Many terminal moraines have also been noticed on the southern flank of the Pirpanjal at altitudes of somewhat less than $8,900 \mathrm{ft}$. ; but no traces of the Pleistocene glaciation have been so far discovered anywhere in the Jammu Hills south of the Pirpanjal.

My colleague, Mr. T. R. Bhatia, and I recently visited Tringla, close to Batote hill station 78 miles from Jammu. Batote is situated at lat. $33 \cdot 7^{\circ}$ and long. $75 \cdot 20^{\circ}$ at an altitude about $5,000 \mathrm{ft}$. above sea. level. This hill station and the entire country from Udhampur to Peera and leading to Srinagar, Murree and beyond in West Pakistan, to Teetwal in the north-west and for a considerable distance eastwards is covered by the rocks belonging to the Murree series, of Oligocene and Lower Miocene age.

Our attention was attracted in this series by a few outcrops of the compact and hard sandstone which showed an unusual degree of smoothness. A closer examination of these outcrops revealed a number of grooves, roughly parallel to one another, running in a north-south direction and 5-9 in. long. Evidently these were glacial striæ on the polished sandstone dipping roughly southwards at an angle of about $40^{\circ}$, furmishing convincing proofs of their having been produced by glacial action during the Pleistocene Ice Age. The grooves possessed a virtually original freshness and appeared to have been rubbed off from the neighbouring polished surface. In one sandstone projection a fairly large cut with polished sides was seen. This must have been earved by the silt-charged water when the ice was in the process of melting. Further investigation near the same spot showed a number of large boulders with polished and grooved surfaces. On one of them the grooves were intact, but the polish had completely gone. Similar observations were made about 1 mile to the east towards the Chakou Nala.

In our opinion, the Patni Top area south of Batote, altitude $7,000 \mathrm{ft}$., served as the gathering ground for the snow and ice during the Pleistocene times and from this snowfield one or more glaciers descended northwards towards Batote. The entire Patni Top area has at present the topography of a big cirque now breached by a couple of small streams.

\section{R. C. Mehdiratta}

University of Jammu and Kashmir, Srinagar.

Dec. 1.

${ }^{1}$ Geol. Surv. Ind., Mem, 49, Pt. 2.

\section{Niobium-Zirconium-Thorium-Uranium and Rare-Earth Minerals from the Pegmatites of South Harris, Outer Hebrides}

DURING a recent examination of some of the pegmatites in the Lewisian rocks of South Harris a suite of rare minerals was found which may stimulate further research into the numerous, but somewhat neglected, pegmatite occurrences in other parts of the Lewisian of north-west Scotland.

References to the South Harris pegmatites have been made from time to time ${ }^{1-4}$, and Holmes, Shillibeer and Wilson ${ }^{5}$ estimated the age of the potashfelspars from the Chiapaval and Roneval pegmatites by the potassium-argon method and found them to be $1,110 \pm 70$ million years, and $1,140 \pm 70$ million years, respectively.

In the earlier part of the Second World War, the Chiapaval pegmatite near Northton and the Sletteval pegmatites east of Roneval were opened out and quarried for potash-felspar on a considerable scale. These large quarries attracted our interest, and a search for rare minerals was made.

The Chiapaval pegmatite vein, which stretches for a mile, and in places is up to $80 \mathrm{ft}$. thick, consists of 